\title{
EVALUATION OF THE MECHANICAL AND PHYSICAL PROPERTIES OF PARTICLEBOARD MANUFACTURED FROM CANOLA (Brassica napus) STRAWS
}

\author{
Behzad Kord $^{1, \star}$, Hossein Zare ${ }^{2}$, Abdollah Hosseinzadeh ${ }^{3}$
}

\begin{abstract}
This study examined possible feasibility of canola (Brassica napus) straws in the production of particleboard. Three-layer experimental particleboards with density $0,7 \mathrm{~g} / \mathrm{cm}^{3}$ were manufactured using different canola straws particle ratios $(0 \%, 25 \%, 50 \%, 75 \%$ and $100 \%)$ and urea formaldehyde (UF) adhesive. Modulus of elasticity (MOE), modulus of rupture (MOR), internal bond strength (IB), water absorption (WA) and thickness swelling (TS) properties of the boards were evaluated and a statistical analysis was performed in order to examine possible feasibility of these straws in commercial particleboard manufacturing. The results indicated that, the addition of canola straws particle significantly improved modulus of rupture and modulus of elasticity of the panels and greatly reduced their internal bonding. Overall findings showed that most panels made from above-mentioned materials exceed the EN Standards for MOR, MOE and IB. Also, the water absorption and thickness swelling increased with increasing canola straws content in the panels. The experimental results have shown that production of general purpose and furniture grade particleboard used in dry conditions using canola straws is technically viable. The results of the study demonstrate that canola straws can be an alternative raw material source for particleboard industry.
\end{abstract}

Keywords: Canola straws, mechanical properties, particleboards, physical properties, urea formaldehyde.

\section{INTRODUCTION}

Particleboard is an engineered wood composite manufactured from wood particles, such as saw mill shavings, chips, or even sawdust, and a synthetic resin or other suitable binder, which is pressed. It has found typical applications as furniture, cabinets, flooring, table, counter and desktops, office dividers, wall and ceiling, stair treads, home constructions, sliding doors, kitchen worktops, interior signs, bulletin boards, and other industrial products (Nemli and Aydin 2007, Wang et al. 2008, Akyuz et al. 2010, Marzbani et al. 2015).

It is well known that the worldwide demand for particleboard has been growing over the last 20 years. Particleboard is $57 \%$ of total consumption of wood-based panels consumed and it is continuously growing at $2-5 \%$ annually. Particleboard consumption significantly increases each year (Ashoria and Nourbakhsh 2008). According to a report from Food and Agricultural Organization (FAO) of the United Nations, during 1998 world consumption of particleboard was $56,2 \times 10^{6} \mathrm{~m}^{3}$ and in 2012 it had risen to approximately $98 \times 10^{6} \mathrm{~m}^{3}$ (FAO 2012).

\footnotetext{
${ }^{1}$ Assistant professor, Department of Paper and Packaging Technology, Faculty of Chemistry and Petrochemical Engineering, Standard Research Institute (SRI), Karaj, Iran.

${ }^{2} \mathrm{MSc}$ Graduate, Department of Wood and Paper Science and Technology, Islamic Azad University, Chalous Branch , Iran.

${ }^{3}$ Assistant Professor, Department of Wood Science and Paper Technology, Islamic Azad University, Chalous Branch , Iran.

•Corresponding author: b.kord@standard.ac.ir

Received: 13.01.2015 Accepted: 01.10.2015
} 
Considering the fact that the raw materials especially in natural resources sector are limited, the wood-working industry has made several efforts to ensure the sustainability of raw materials. Therefore, for providing wooden raw materials, special attention should be paid to wood wastes/residues from wood-working industries and agricultural residues, because the particleboard industry is able to use and consume a wide range of wooden and nonwooden lignocellulosic wastes/residues (Troger et al. 1998, Nemli et al. 2003, Bektas et al. 2005, Guntekin and Karakus 2008). Alternative raw materials such as agricultural residues and fast-growing species can play an important role in the particleboard industry in the future (Nemli et al. 2009, Papadopoulos et al. 2004, de Melo et al. 2014, 2015). Iran as a developing country does not have sufficient raw material to supply its forest industry demands. Consequently, several researchers in Iran have investigated the suitability of some underutilized species as well as bio-based residues; date palm, mesquite, salt cedar and eucalyptus wood (Ashoria and Nourbakhsh 2008), almond shell (Pirayesh and Khazaeian 2012), wheat straw (Tabarsa et al. 2011, Azizi et al. 2011), walnut shell (Pirayesh et al. 2012), walnut/almond shell (Pirayesh et al. 2013), reed (Dahmardeh Ghalehno et al. 2011) and cotton (Khanjanzadeh et al. 2012) in the production of woodbased composites.

Canola (Brassica napus) is an important crop that is cultivated in a considerable growth in Iran during the past decade. The average straw yield of canola reaches about 3 dry $t / h a$. It can be estimated that about 500000 tons of canola straw is produced in Iran annually and due to the governmental policies to supply Edible oil, this amount will increase in the future. It is interesting to mention that canola straw has no special industrial application. Large quantities of canola straw remain in the fields every year after harvesting (Yousefi 2009). Value-added wood-based panels made from these residual agricultural can be considered as optimum way of utilizing available resources. Canola straw could play an important role in the manufacture of value-added wood-based panels such as particleboards and may be more efficient use of these materials. There is no information on using canola straw particles in particleboard manufacturing. Therefore, the objective of this work was to evaluate the mechanical and physical properties of particleboard containing particles of canola straws in production of three-layer particleboard.

\section{EXPERIMENTAL}

\section{Materials}

The raw material of this study consisted of canola (Brassica napus L.) straws which collected from the field in Gorgan, Iran, and wood particles consisting of alder (Alnus subcordata), eucalyptus (Eucalyptus grandis), poplar (Populus nigra), beech (Fagus orientalis) and Maple (Acer saccharum) species were obtained from a particleboard plant in Amol, Iran. The adhesive was urea-formaldehyde (UF) which produced by a local plant with characteristics given in table 1 . Ammonium chloride $\left(\mathrm{NH}_{4} \mathrm{Cl}\right)$ solution (solid content: $20 \%$ ) was used as a hardener.

Table 1. Properties of the adhesives.

\begin{tabular}{cc}
\hline Properties & UF \\
\hline Solid $(\%)$ & 50 \\
Density $\left(\mathrm{kg} / \mathrm{m}^{3}\right)$ & 1220 \\
$\mathrm{PH}$ & 7,5 \\
Viscosity $(\mathrm{Pa} . \mathrm{s})$ & 0,015 \\
Gel point $\left(100^{\circ} \mathrm{C}\right)$ & 55 \\
\hline
\end{tabular}




\section{Methods}

Canola straws were first cleaned of dirt and impurities then chipped using an industrial-scale drumchipper and then crushed by a knife-ring flaker to obtain fine canola particles. The average size of canola particles was $17,79 \mathrm{~mm}$ in length; $2,55 \mathrm{~mm}$ in width and $0,49 \mathrm{~mm}$ in thickness and wood particles averaged $12,49 \times 2,73 \times 0,65 \mathrm{~mm}$. Average density, slenderness ratio and specific surface of particles are presented in table 2 .

Table 2. Geometrical data of particles.

\begin{tabular}{cccc}
\hline Particles & Density $\left(\mathrm{kg} / \mathrm{m}^{3}\right)$ & Slenderness ratio & Specific surface $\left(\mathrm{cm}^{2} / \mathrm{g}\right)$ \\
\hline Wood & 580 & 19,21 & 53,05 \\
Canola & 270 & 36,31 & 151,17 \\
\hline
\end{tabular}

Next the chipped canola and wood particles were classified in laboratory shaker. The particles remained between 3-1,5 $\mathrm{mm}$ and 1,5-0,8 $\mathrm{mm}$ sieve was utilized in the core and outer layers, respectively. Particles were oven dried at $100 \pm 3{ }^{\circ} \mathrm{C}$ to reach the target moisture content (3\%). Ureaformaldehyde (UF) resin at $8 \%$ and $10 \%$ levels (based on oven dry weight of the particles) was used for the core and outer layers respectively. Two-percent ammonium chloride $\left(\mathrm{NH}_{4} \mathrm{Cl}\right)$ was also added to the resin as a hardener. Particleboard panels were manufactured using standardized procedures that simulated industrial production at the laboratory. The particles were placed in a rotating drum-type blender and sprayed with resin and ammonium chloride for $5 \mathrm{~min}$ to obtain a homogenized mixture. The glued particles then were pressed into panel mat using a laboratory scale hydraulic hot press. Thickness of panels was controlled by stop bars and panels target density was $700 \mathrm{~kg} / \mathrm{m}^{3}$. No wax or any other additives were applied for panel manufacturing. Three panels were produced for each group. The experimental design is shown in table 3 . The dimensions of the produced particleboards were $32 \times 30 \times 1,5 \mathrm{~cm}$.

Table 3. Experimental design.

\begin{tabular}{ccc}
\hline \multirow{2}{*}{ Board type } & \multicolumn{2}{c}{ Raw material } \\
\cline { 2 - 3 } & Canola (\%) & Wood (\%) \\
\hline A & 0 & 100 \\
B & 25 & 75 \\
D & 50 & 50 \\
E & 75 & 25 \\
E & 100 & 0 \\
\hline
\end{tabular}

The produced particleboards conditioned at $20{ }^{\circ} \mathrm{C}$ and $65 \%$ relative humidity to reach moisture content of about $12 \%$ before trimming to final dimension of $25 \times 25 \times 15 \mathrm{~cm}$. The panel production parameters were also displayed in table 4.

Table 4. Production parameters of particleboards.

\begin{tabular}{lc}
\hline \multicolumn{1}{c}{ Parameter } & Value \\
\hline Press temperature $\left({ }^{\circ} \mathrm{C}\right)$ & 170 \\
Pressing time $(\mathrm{min})$ & 7 \\
Press pressure $\left(\mathrm{kg} / \mathrm{cm}^{2}\right)$ & 30 \\
Press closing rate $(\mathrm{mm} / \mathrm{min})$ & 4,5 \\
Hardener $(\%)$ & 2 \\
Thickness $(\mathrm{mm})$ & 15 \\
Target density $\left(\mathrm{kg} / \mathrm{m}^{3}\right)$ & 700 \\
\hline
\end{tabular}


Some mechanical properties: modulus of rupture (MOR) (EN 310, 1993), modulus of elasticity (MOE) (EN 310, 1993) and internal bonding strength (IB) (EN 319, 1993) and physical properties: water absorption (WA) and thickness swelling (TS) (EN 317, 1993) were determined for the produced particleboards. The average of 5 and 10 measurements were reported for mechanical and physical properties respectively.

Data for each test were statistically analyzed using analysis of variance (ANOVA). When the ANOVA indicated a significant difference among factors and levels, a comparison of the means was done employing Duncan test to identify which groups were significantly different from other groups at $99 \%$ confidence level.

\section{RESULTS AND DISCUSSION}

\section{Mechanical properties}

Figures 1 and 2 illustrate the MOR and MOE values of the experimental panels. The highest MOR (18,65 MPa) and MOE (2770 MPa) values were measured type E, including $100 \%$ canola straw. Besides, the lowest MOR (15,50 MPa) and MOE (2221 MPa) values were determined for particleboard produced using industrial wood particles. The result indicated that the canola straw content in the mixture significantly increased the MOR and MOE values of the particleboards. Significant differences between group averages for the MOR and MOE values were determined individually for these tests by Duncan's multiple comparison tests. The results of Duncan's grouping are shown in figures 1 and 2 by letters. All panel types showed statistically significant differences $(\mathrm{P}<0,01)$ in their MOR and MOE properties from each other. Based on the EN 312 (EN 312, 2005) standard; 11,5 and 13,0 N/mm² are the minimum requirements for MOR of particleboards for general uses and interior fitments (including furniture), respectively, while the minimum requirement for MOE of particleboards for interior fitments is $1600 \mathrm{~N} / \mathrm{mm}^{2}$. All of the particleboard types had higher MOR and MOE for general purposes. The improvement in the MOR and MOE values of samples containing different canola straw particles can be attributed to to the low density of canola particles which causes more compactness at the surface. This in turn leads to better adhesion during hot pressing. Similar results were also stated for panels made using underutilized raw material as well as agricultural wastes and residues by Papadopoulos et al. (2004), Tabarsa et al. (2011), Azizi et al.(2011), Dahmardeh Ghalehno et al. (2011), Khanjanzadeh et al. (2012).

The geometry of particle may substantially affect the quality of bonding among particles and consequently influence the strength and stiffness of the manufactured boards. In the development of board properties, particle geometry has much greater influence on the board properties than the actual mechanical properties of the particles themselves (Juliana et al. 2012). Theoretically, thinner and longer particle would give a higher aspect ratio, hence provides larger contact areas between the particles, as compared to thicker and shorter particle. Aspect ratio is commonly described as length of the particles divided by its width. Particles can also be described based on its slenderness ratio, i.e. the length divided by the thickness (Nishimura et al. 2004). Hence in particleboard, both slenderness and aspect ratios are often used together to describe the flexibility of a particle. Slender particles would usually give better bonding than stout particles due to greater amount of contact surface area. The MOR and MOE increment perhaps was due to the higher specific surface and more slender canola straw particles than wood particles. Hence, the produced boards attained higher strengths when canola straw particles were incorporated, irrespective of the type of wood particles used. 


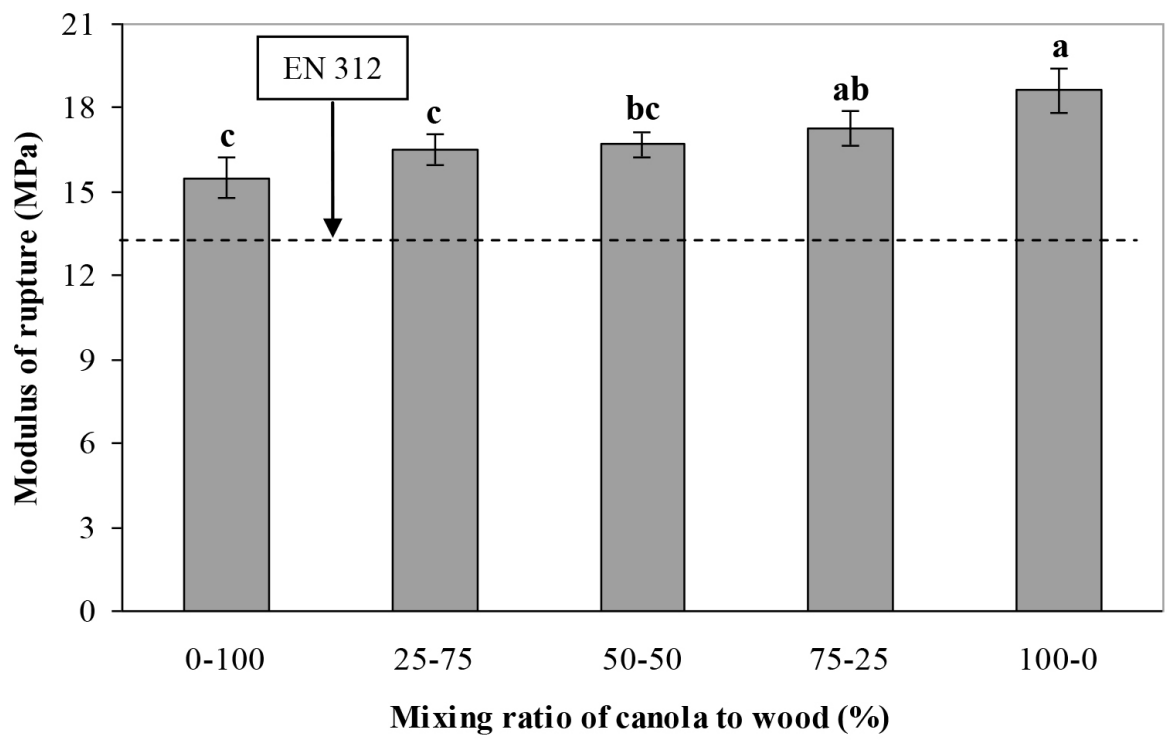

Figure 1. Modulus of rupture of experimental panels (values are mean \pm standard deviation).

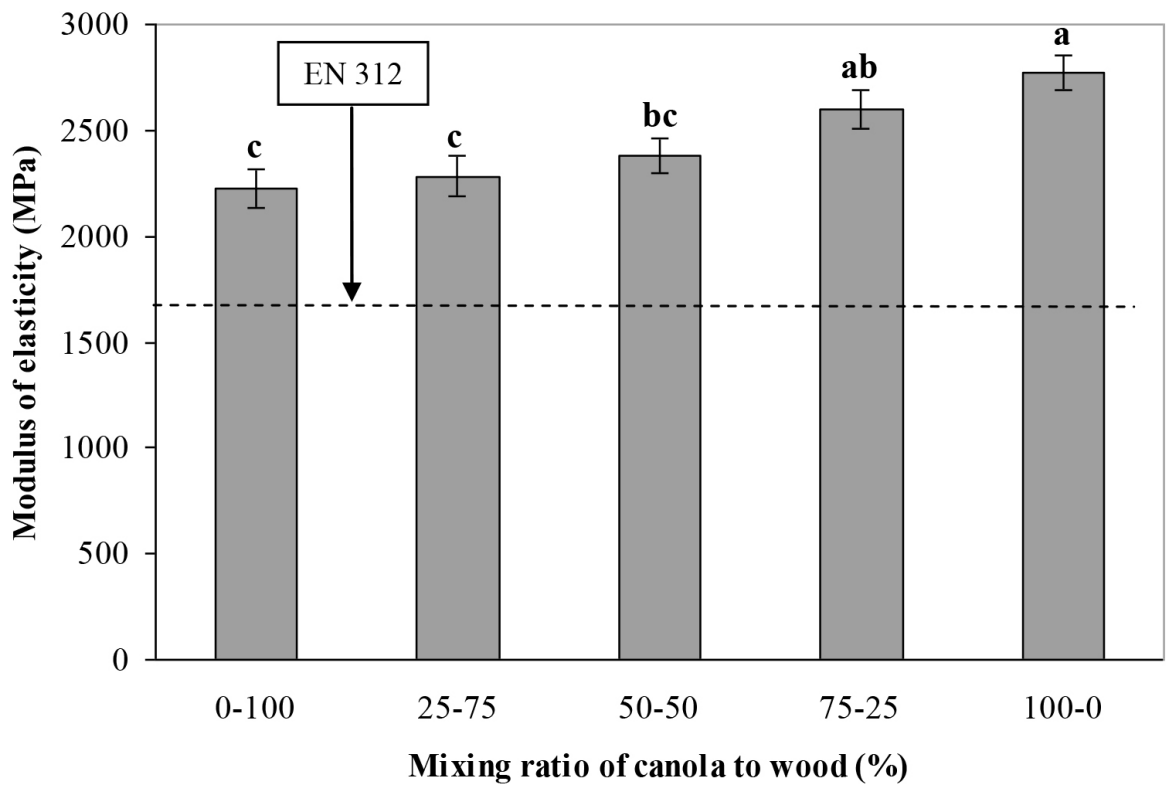

Figure 2. Modulus of elasticity of experimental panels (values are mean \pm standard deviation).

IB values of the experimental panels ranged from 0,34 to $0,91 \mathrm{MPa}$. The highest IB value was observed for panel A while the lowest was recorded for E type panel. IB values decreased with the increasing the canola straw particles content in the panels (Figure 3). All panel types showed statistically significant differences $(\mathrm{P}<0,01)$ in IB values with each other. The minimal requirement of internal bond strength for general purpose, interior fitments and load-bearing boards, and for heavy duty loadbearing boards are 0,$24 ; 0,35$ and $0,50 \mathrm{MPa}$, respectively (EN 312,2005). All of the produced panels 
met requirement for general purpose end-use while $\mathrm{A}, \mathrm{B}$ and $\mathrm{C}$ type particleboards met the minimum requirement for heavy duty load-bearing boards, and panel types D and $\mathrm{E}$ satisfied the minimum IB requirements for interior fitments including furniture manufacture stated in the EN 312 standard. There is a reduction in the internal bonding values of samples as the canola straws addition. This is probably attributed to lower adhesive content per surface area of canola straw particles in comparison to wood particles. This is due to the fact that canola straw are wider and considerably thinner, and consequently have a much larger surface area per weight unit than wood particles. This finding is also compatible with previous literature (Bektas et al. 2005, Nemli et al. 2009, Azizi et al. 2011).

In such condition, more adhesives are also required to sufficiently bond the particles. Similarly at higher aspect ratios, the specific surface areas of longer particles are lower than those of shorter ones of the same species and thickness due to the higher surfaces of the fiber cross sections. Thus, the adhesive content per unit particle surface area is higher for long particles than for short ones at a given adhesive content (Nishimura et al. 2004, Juliana et al. 2012). Therefore, it is anticipated that particleboards made from canola straw particles would have lower internal bonding strength than boards made from wood particles.

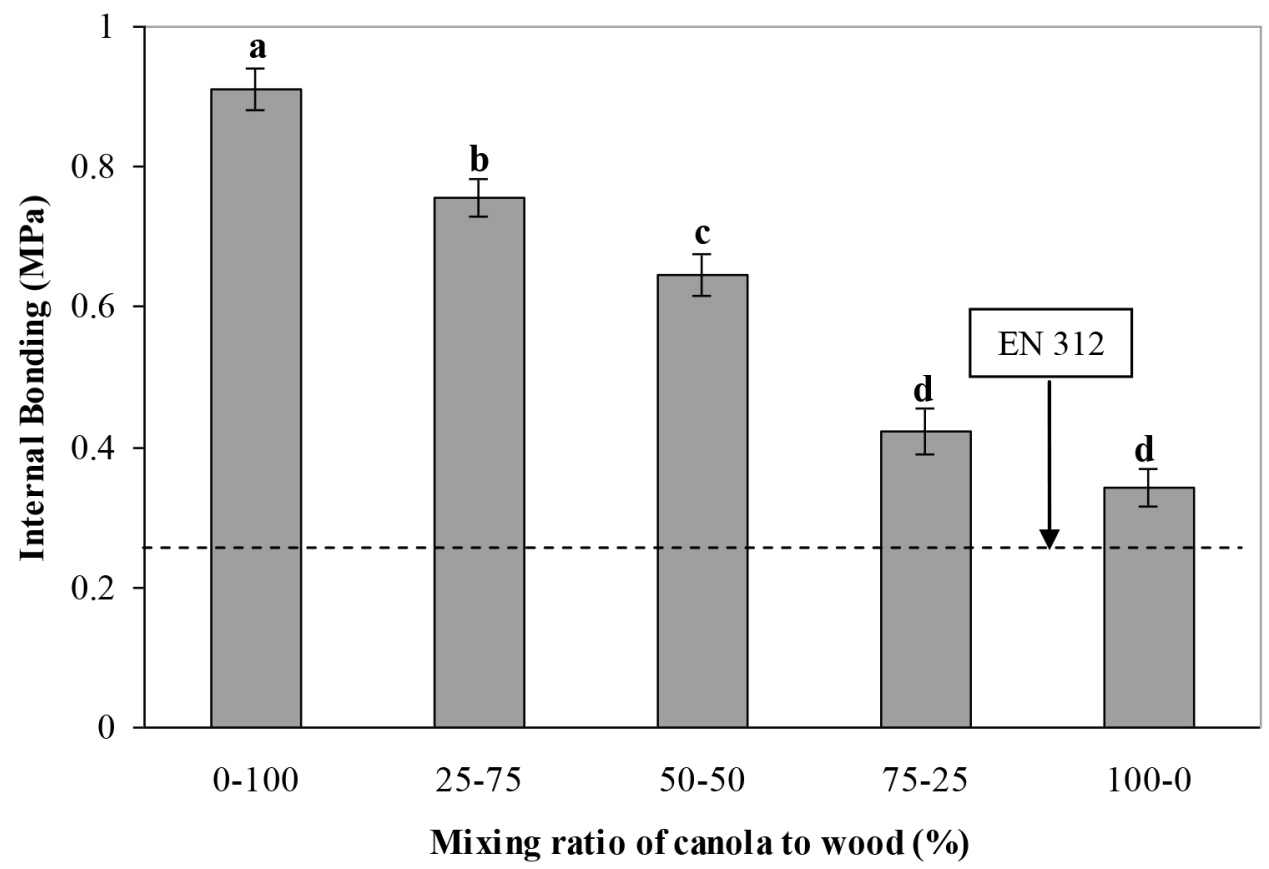

Figure 3. Internal bonding of experimental panels (values are mean \pm standard deviation).

\section{Physical properties}

The addition of canola straw particles into particleboard significantly increased the WA and TS values of the experimental panels for $24 \mathrm{~h}$ immersion in water (Figures 4 and 5). The minimum values of WA $(35,7 \%)$ and TS $(10,18 \%)$ was measured for particleboard produced using industrial wood particles. Besides, the highest WA $(70,9 \%)$ and TS $(27,48 \%)$ values were measured type E, including $100 \%$ canola straw. Significant differences between group averages for the WA and TS values were determined individually for these tests by Duncan's multiple comparison tests. The results of Duncan's grouping are shown in figures 4 and 5 by letters. All panel types showed statistically significant differences $(\mathrm{P}<$ $0,01)$ in their WA and TS properties from each other. Based on EN standards, particleboard should have a maximum TS value of $8 \%$ for $2 \mathrm{~h}$ water immersion. Furthermore, according to EN 312-4 the maximum TS requirement for $24 \mathrm{~h}$ water immersion is $15 \%$. Panel types A and B was found to comply 
with particleboard maximum property requirement of $14 \%$ for $24 \mathrm{~h}$ water immersion based on EN 312 (EN 312, 2005) for use in non load-bearing applications in humid conditions except for panel types C, D and E. Increasing water absorption and thickness swelling by increasing canola straws may be attributed to the presence of high amount of pith in these materials than its wood. As pith consist parenchyma cells, which are softer and shorter than the other cells, strength properties of these cells are low. The parenchyma is more hygroscopic compared to other cells, naturally spongy and have high capacity in water absorption to store in the tissue cell (Ramle et al. 2012, Abdullah et al. 2012). This result is due to the fact that canola straw contains a higher proportion of parenchyma tissues, which leads to the greater affinity to absorb water. On the other hand, the presence of more hydroxyl group in the parenchyma tissue that enables more hydrogen bonding formation. In addition, the parenchyma behaved like a sponge making it easier for the panels to absorb water. Similar results were reported in previous studies (Ntalos and Grigoriou 2002, Kalaycioglu and Nemli 2006, Dahmardeh Ghalehno et al. 2011).

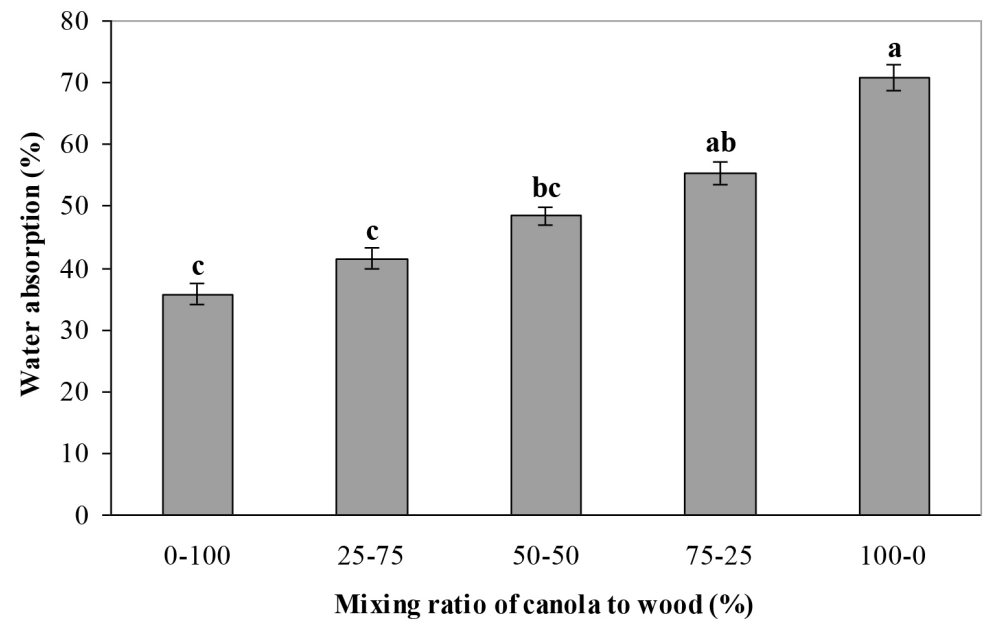

Figure 4. Water absorption of experimental panels for $24 \mathrm{~h}$ immersion in water (values are mean \pm standard deviation).

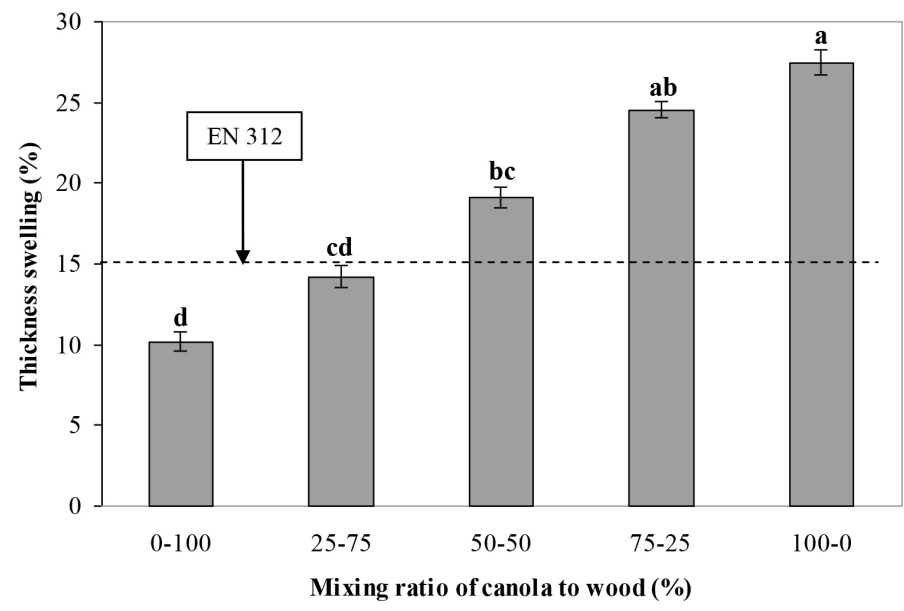

Figure 5. Thickness swelling of experimental panels for $24 \mathrm{~h}$ immersion in water (values are mean \pm standard deviation). 
It is noted that the differences between vertical density profiles of the panels were observed, although these data have been not reported.

\section{CONCLUSIONS}

This study investigated the feasibility of using canola straws in the manufacture of three-layer particleboard. The results indicated that the modulus of rupture, modulus of elasticity, water absorption and thickness swelling increased with increasing canola straws content in the panels. However, the canola straw content in the mixture significantly decreased the internal bonding values of the particleboards. Most type panels were found to comply with MOR, MOE and IB requirement of the EN Standards. Use of renewable materials such as canola straws for manufacturing particleboards could contribute the solution of raw material shortage for the particleboard industry and some environmental problems due to the burning can be prevented. The experimental results have shown that production of general purpose and furniture grade particleboard used in dry conditions using canola straws is technically viable.

\section{REFERENCES}

Abdullah, C.K.; Jawaid, M.; Abdul Khalil, H.P.S.; Zaidon, A.; Hadiyane, A. 2012. Oil palm trunk polymer composite: Morphology, water absorption and thickness swelling behaviors. Bioresource 7(3): 2948-2959.

Akyuz, K.C.; Nemli, G.; Baharoglu, M.; Zekovic, E. 2010. Effects of acidity of the particles and amount of hardener on the physical and mechanical properties of particleboard composite bonded with urea formaldehyde. Int $J$ Adhes Adhes 30: 166-169.

Ashoria, A.; Nourbakhsh, A. 2008. Effect of press cycle time and resin content on physical and mechanical properties of particleboard panels made from the underutilized low-quality raw materials. Ind Crops Prod 28: 225-230.

Azizi, K.; Tabarsa, T.; Ashori, A. 2011. Performance characterizations of particleboards made with wheat straw and waste veneer splinters. Compos Part B 42: 2085-2089.

Bektas, I.; Guler, C.; Kalaycioglu, H.; Mengenoglu, F.; Nacar, M. 2005. The manufacture of particleboards using sunflower stalks (Helianthusannuus I.) and poplar wood (Populus alba L.). $J$ Compos Mater 39: 467-473.

Dahmardeh Ghalehno, M.; Madhoushi, M.; Tabarsa, T.; Nazerian, M. 2011. The manufacture of particleboards using mixture of reed (surface layer) and commercial species (middle layer). Eur $J$ Wood Prod 69(3): 341-344.

EN 310. 1993. Wood-based panels, determination of modulus of elasticity in bending and bending strength. Brussels (Belgium): European Committee for Standardization.

EN 319. 1993. Particleboards and fiberboards, determination of tensile strength perpendicular to plane of the board. Brussels (Belgium): European Committee for Standardization.

EN 317. 1993. Particleboards and fiberboards, determination of swelling in thickness after immersion. Brussels (Belgium): European Committee for Standardization.

EN 312. 2005. Particleboards-specifications. Brussels (Belgium): European Committee for Standardization. 
FAO. 2012. Forest product statistics, Global forest products facts and figures. http://www.fao.org/ forestry/statistics.

Juliana, A.H.; Paridah, M.T.; Rahim, S.; Nor Azowa, I.; Anwar, U.M.K. 2012. Properties of particleboard made from kenaf (Hibiscus cannabinusL.) as function of particle geometry. Mater Des 34: 406-411.

Guntekin, E.; Karakus, B. 2008. Feasibility of using eggplant (Solanum melongena) stalks in the production of experimental particleboard. Ind Crops Prod 27: 354-358.

Kalaycioglu, H.; Nemli, G. 2006. Producing composite particleboard from kenaf (Hibiscus cannabinus L.) stalks. Ind Crops Prod 24(2): 177-180.

Khanjanzadeh, H.; Bahmani, A.; Rafighi, A.; Tabarsa, T. 2012. Utilization of bio-waste cotton (Gossypium hirsutum L.) stalks and underutilized paulownia (Paulownia fortunie) in wood-based composite particleboard. Afric J Biotech 11(31): 8045-8050.

Marzbani, P.; Afrouzi, Y.M.; Omidvar, A. 2015. The effect of nano-zinc oxide on particleboard decay resistance. Maderas Cienc Tecnol 17(1): 63-68.

de Melo, R.R.; Stangerlin, D.M.; Santana, R.R.C.; Pedrosa, T.D. 2015. Decay and termite resistance of particleboard manufactured from wood, bamboo and rice husk. Maderas Cienc Tecnol 17(1): 55-62.

de Melo, R.R.; Stangerlin, D.M.; Santana, R.R.C.; Pedrosa, T.D. 2014. Physical and mechanical properties of particleboard manufactured from wood, bamboo and rice husk. Mater Res 17(3): 682-686.

Nemli, G.; Kirci, H.; Serdar, B.; Ay, N. 2003. Suitability of kiwi (Actinidia sinensis Planch.) pruning for particleboards manufacturing. Ind Crops Prod 17(1): 39-46.

Nemli, G.; Aydin, A. 2007. Evaluation of the physical and mechanical properties of particleboard made from the needle litter of Pinus pinaster Ait. Ind Crops Prod 26(3): 252-258.

Nemli, G.; Demirel, S.; Gümüokaya, E.; Aslan, M.; Acar, C. 2009. Feasibility of incorporating waste grass clippings (Lolium perenne L.) in particleboard composites. Waste Manage 29: 1129-1131.

Nishimura, T.; Amin, J.; Ansell, M.P. 2004. Image analysis and bending properties of model OSB panels as a function of strand distribution, shape and size. Wood Sci Technol 38: 297-309.

Ntalos, G.A.; Grigoriou, A.H. 2002. Characterization and utilization of wine pruning as a wood substitute for particleboard production. Ind Crops Prod 16: 59-68.

Papadopoulos, A.N.; Hill, C.A.S.; Gkaraveli, A.; Ntalos, G.A.; Karastergiou, S.P. 2004. Bamboo chips (Bambusa vulgaris) as an alternative lignocellulosic raw material for particleboard manufacture. Holz Roh-Werkst 62: 36-39.

Pirayesh, H.; Khazaeian, A. 2012. Using almond (Prunus amygdalus L.) shell as a biowaste resource in wood based composite. Compos Part B 43: 1475-1479.

Pirayesh, H.; Khazaeian, A.; Tabarsa, T. 2012. The potential for using walnut (Juglans regia L.) shell as a raw material for wood-based particleboard manufacturing. Compos Part B 43: 3276-3280.

Pirayesh, H.; Khanjanzadeh, H.; Salari, A. 2013. Effect of using walnut/almond shells on the physical, mechanical properties and formaldehyde emission of particleboard. Compos Part B 45: 858863.

Ramle, S.F.M.; Sulaiman, O.; Hashim, R.; Arai, T.; Kosugi, A.; Abe, H.; Murata, Y.; Mori, Y. 2012. Characterization of parenchyma and vascular bundle of oil palm trunk as function of storage time. Lignocel 1(1): 33-44. 
Tabarsa, T.; Jahanshahi, S.; Ashori, A. 2011. Mechanical and physical properties of wheat straw boards bonded with a tannin modified phenol-formaldehyde adhesive. Compos Part B 42(2): 176-180.

Troger, F.; Wegener, G.; Seeemann, C. 1998. Mischantus and flax as raw material for reinforced particleboards. Ind Crops Prod 8 (2): 113-121.

Wang, S.Y.; Yang, T.H.; Lin, L.T.; Lin, C.J.; Tsai, M.J. 2008. Fire retardant treated low formaldehyde emission particleboard made from recycled wood waste. Bioresour Technol 99: 20722077.

Yousefi, H. 2009. Canola straw as a bio-waste resource for medium density fiberboard (MDF) manufacture. Waste Manage 29: 2644-2648. 